\title{
The changing role of organic nitrates in the removal and transport of $\mathrm{NO}_{x}$
}

\author{
Paul S. Romer Present ${ }^{1}$, Azimeh Zare ${ }^{1}$, and Ronald C. Cohen ${ }^{1,2}$ \\ ${ }^{1}$ Department of Chemistry, University of California Berkeley, Berkeley, CA 94720, USA \\ ${ }^{2}$ Department of Earth and Planetary Sciences, University of California Berkeley, Berkeley, CA 94720, USA
}

Correspondence: Ronald C. Cohen (rccohen@berkeley.edu)

Received: 18 May 2019 - Discussion started: 23 May 2019

Revised: 5 October 2019 - Accepted: 3 November 2019 - Published: 7 January 2020

\begin{abstract}
A better understanding of the chemistry of nitrogen oxides $\left(\mathrm{NO}_{x}\right)$ is crucial to effectively reducing air pollution and predicting future air quality. The response of $\mathrm{NO}_{x}$ lifetime to perturbations in emissions or in the climate system is set in large part by whether $\mathrm{NO}_{x}$ loss occurs primarily by the direct formation of $\mathrm{HNO}_{3}$ or through the formation of alkyl and multifunctional nitrates $\left(\mathrm{RONO}_{2}\right)$. Using 15 years of detailed in situ observations, we show that in the summer daytime continental boundary layer the relative importance of these two pathways can be well approximated by the relative likelihood that $\mathrm{OH}$ will react with $\mathrm{NO}_{2}$ or instead with a volatile organic compound (VOC). Over the past decades, changes in anthropogenic emissions of both $\mathrm{NO}_{x}$ and VOCs have led to a significant increase in the overall importance of $\mathrm{RONO}_{2}$ chemistry to $\mathrm{NO}_{x}$ loss. We find that this shift is associated with a decreased effectiveness of $\mathrm{NO}_{x}$ emissions reductions on ozone production in polluted areas and increased transport of $\mathrm{NO}_{x}$ from source to receptor regions. This change in chemistry, combined with changes in the spatial pattern of $\mathrm{NO}_{x}$ emissions, is observed to be leading to a flatter distribution of $\mathrm{NO}_{2}$ across the United States, potentially transforming ozone air pollution from a local issue into a regional one.
\end{abstract}

\section{Introduction}

Nitrogen oxides $\left(\mathrm{NO}_{x} \equiv \mathrm{NO}+\mathrm{NO}_{2}\right)$ play a central role in the formation of toxic air pollutants including $\mathrm{O}_{3}$ and secondary aerosols. More broadly, $\mathrm{NO}_{x}$ chemistry controls the rates and pathways of atmospheric oxidation by determining the concentration of the three most important tropospheric oxidants:
$\mathrm{OH}, \mathrm{O}_{3}$, and $\mathrm{NO}_{3} . \mathrm{NO}_{x}$ emissions also directly contribute to nitrogen deposition in sensitive ecosystems (Fowler et al., 2013). Due to its harmful effects to the environment and human health, $\mathrm{NO}_{x}$ has been the target of emissions control strategies since the 1970s, causing anthropogenic $\mathrm{NO}_{x}$ emissions in the United States to have decreased by a factor of 2 or more over the past 30 years (United States Environmental Protection Agency, 2018). Understanding the consequences of these past changes and predicting the results of future emissions reductions on the atmosphere requires a quantitative description of feedbacks between $\mathrm{NO}_{x}$ concentrations and $\mathrm{NO}_{x}$ chemistry.

After emission to the atmosphere, removal of $\mathrm{NO}_{x}$ occurs through two primary pathways: conversion to $\mathrm{HNO}_{3}$ and conversion to alkyl and multifunctional nitrates $\left(\mathrm{RONO}_{2}\right)$. Once formed, $\mathrm{HNO}_{3}$ is nearly chemically inert in the troposphere, with a lifetime to reaction or photolysis of over $50 \mathrm{~h}$. $\mathrm{HNO}_{3}$ is therefore removed almost entirely by wet and dry deposition. $\mathrm{RONO}_{2}$ represents a class of diverse molecules, with atmospheric lifetimes ranging from hours to days depending on the properties of the organic backbone (R group). The loss of $\mathrm{RONO}_{2}$ is divided among reactions that release $\mathrm{NO}_{x}$ from the $\mathrm{R}$ group and recycle it back to the atmosphere, reactions that result in heterogeneous hydrolysis to form $\mathrm{HNO}_{3}$, and direct deposition. The later two pathways permanently remove $\mathrm{NO}_{x}$ from the atmosphere (Nguyen et al., 2015; Romer et al., 2016; Fisher et al., 2016). Other $\mathrm{NO}_{x}$ oxidation products, such as peroxy acetyl nitrate (PAN) or $\mathrm{HONO}$, can play an important role in the transport and redistribution of $\mathrm{NO}_{x}$ but do not generally lead to permanent $\mathrm{NO}_{x}$ removal. 
Historically, direct $\mathrm{HNO}_{3}$ production was thought to be the only important $\mathrm{NO}_{x}$ loss pathway, with $\mathrm{RONO}_{2}$ chemistry playing at most a minor role. However, several studies have shown that the formation rate of $\mathrm{RONO}_{2}$ in cities or forested regions can be competitive with or greater than the direct production rate of nitric acid (Rosen et al., 2004; Farmer et al., 2011; Browne et al., 2013; Romer et al., 2016; Sobanski et al., 2017).

The relative importance of $\mathrm{HNO}_{3}$ and $\mathrm{RONO}_{2}$ production is an important factor in setting the lifetime of $\mathrm{NO}_{x}$ (Romer et al., 2016), and it affects the response of $\mathrm{NO}_{x}$ loss to temperature (Romer et al., 2018). Due to their different production pathways, the relative importance of $\mathrm{HNO}_{3}$ and $\mathrm{RONO}_{2}$ production also controls how $\mathrm{NO}_{x}$ loss and ozone production are affected by changes to emissions of $\mathrm{NO}_{x}$ or volatile organic compounds (VOCs). By terminating the radical chain reactions, the formation of $\mathrm{RONO}_{2}$ serves to suppress ozone formation in polluted areas (Perring et al., 2010; Farmer et al., 2011; Edwards et al., 2013; Lee et al., 2014). Several studies have also shown that $\mathrm{RONO}_{2}$ can efficiently partition into aerosols, potentially explaining a large portion of secondary organic aerosol in a wide range of environments (Rollins et al., 2012; Pye et al., 2015; Xu et al., 2015b; Lee et al., 2016).

Multiple previous studies have used chemical transport models to investigate how the relative production of $\mathrm{RONO}_{2}$ and $\mathrm{HNO}_{3}$ varies in different environments. Browne and Cohen (2012) modeled $\mathrm{NO}_{x}$ loss over the Canadian boreal forest using WRF-Chem and Fisher et al. (2016) and Zare et al. (2018) studied $\mathrm{NO}_{x}$ loss in the southeast United States using GEOS-Chem and WRF-Chem, respectively. These studies agree that in rural and forested areas with lower $\mathrm{NO}_{x}$ emissions and higher biogenic VOC emissions, $\mathrm{RONO}_{2}$ chemistry is often the largest sink of $\mathrm{NO}_{x}$.

However, these studies diverge in their conclusions about the overall importance of $\mathrm{RONO}_{2}$ chemistry as a $\mathrm{NO}_{x}$ sink and how it is likely to change in the future. In a WRF-Chem simulation identical to those described in Zare et al. (2018), $\mathrm{RONO}_{2}$ chemistry is found to be $60 \%$ or more of the total $\mathrm{NO}_{x}$ loss across broad swathes of the southeast United States (Fig. 1), while Fisher et al. (2016) found $\mathrm{RONO}_{2}$ production to be concentrated in rather small sections of the southeast. Furthermore, Fisher et al. (2016) suggested that the contribution of $\mathrm{RONO}_{2}$ chemistry to $\mathrm{NO}_{x}$ loss across the region is unlikely to change significantly in the future due to the spatial segregation of $\mathrm{NO}_{x}$ and VOC emissions. On the other hand, Zare et al. (2018) and Browne and Cohen (2012) suggested that the contribution of $\mathrm{RONO}_{2}$ chemistry to $\mathrm{NO}_{x}$ loss was likely to grow significantly if anthropogenic $\mathrm{NO}_{x}$ emissions decreased across the United States.

Here we use in situ observations from a collection of 13 different field deployments to investigate how the relative daytime production of $\mathrm{RONO}_{2}$ and $\mathrm{HNO}_{3}$ varies across the United States and how this fraction may change in the future. We show that the relative production of $\mathrm{RONO}_{2}$ and $\mathrm{HNO}_{3}$

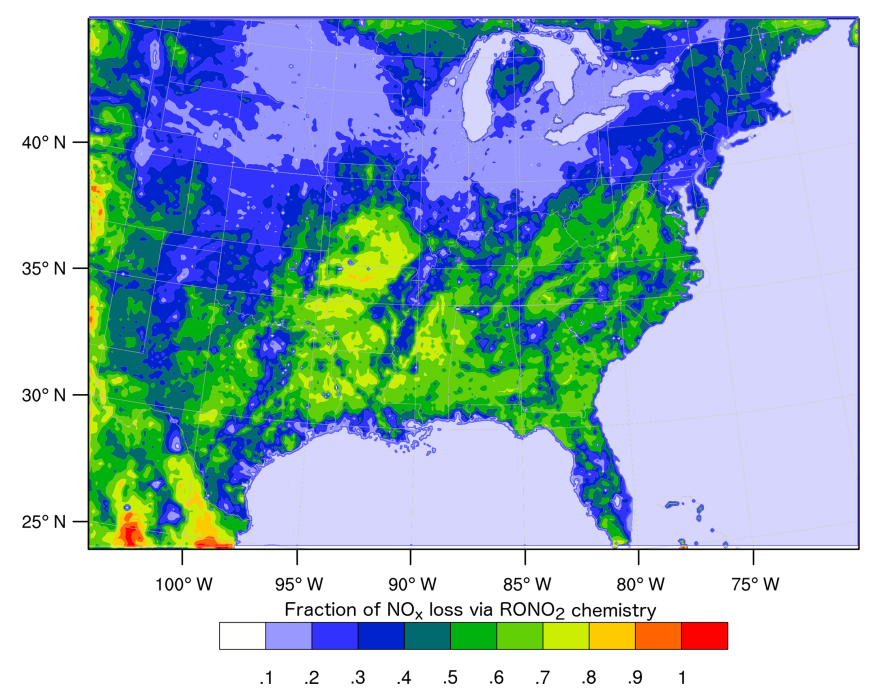

Figure 1. Average (24h) fraction of total $\mathrm{NO}_{x}$ loss via $\mathrm{RONO}_{2}$ chemistry over the southeast United States in summer 2013 simulated using the RACM2_Berkeley2 mechanism in WRF-Chem (Zare et al., 2018).

can be well described by the relative $\mathrm{OH}$ reactivity of $\mathrm{NO}_{2}$ and of the combined VOC mixture. As both anthropogenic $\mathrm{NO}_{x}$ and anthropogenic VOC emissions have decreased substantially in the United States over the past 20 years, the relative role of these two pathways has shifted as well. While the shift has generally been towards an increasing role for $\mathrm{RONO}_{2}$ chemistry, the shift has been smallest in large cities and largest in the transitional regime around them. Combined with changing emission patterns of $\mathrm{NO}_{x}$, the shift in $\mathrm{NO}_{x}$ chemistry is leading to a flatter distribution of $\mathrm{NO}_{x}$ across the continental United States.

\section{$2 \mathrm{NO}_{x}$ chemistry and production of $\mathrm{RONO}_{2}$ and $\mathrm{HNO}_{3}$}

$\mathrm{NO}_{x}$ is emitted to the atmosphere as NO from a range of anthropogenic and biogenic sources, including motor vehicles, power plants, lightning, fires, and soil bacteria. In the daytime, $\mathrm{NO}$ interconverts with $\mathrm{NO}_{2}$ on a timescale of minutes through Reactions (R1-R2), forming the chemical family $\mathrm{NO}_{x}$. When $\mathrm{NO}_{x}$ is combined with VOCs and hydrogen oxides $\left(\mathrm{HO}_{x}\right)$, a set of linked radical chain reactions is formed (Reactions R3-R6). As part of these reactions, two molecules of $\mathrm{NO}$ are oxidized to $\mathrm{NO}_{2}$, leading to the net production of $\mathrm{O}_{3}$ through Reaction (R2).

$$
\begin{aligned}
& \mathrm{NO}+\mathrm{O}_{3} \rightarrow \mathrm{NO}_{2}+\mathrm{O}_{2}, \\
& \mathrm{NO}_{2}+h v+\mathrm{O}_{2} \rightarrow \mathrm{O}_{3}+\mathrm{NO}, \\
& \mathrm{OH}+\mathrm{RH}+\mathrm{O}_{2} \rightarrow \mathrm{RO}_{2}+\mathrm{H}_{2} \mathrm{O}, \\
& \mathrm{RO}_{2}+\mathrm{NO} \stackrel{1-\alpha}{\longrightarrow} \mathrm{RO}+\mathrm{NO}_{2}, \\
& \mathrm{RO}+\mathrm{O}_{2} \rightarrow \mathrm{R}^{\prime} \mathrm{CHO}+\mathrm{HO}_{2},
\end{aligned}
$$


$\mathrm{HO}_{2}+\mathrm{NO} \rightarrow \mathrm{OH}+\mathrm{NO}_{2}$.

The reactions that propagate the catalytic cycle occur at the same time as reactions that remove $\mathrm{NO}_{x}$ from the atmosphere, terminating the cycle. Direct $\mathrm{HNO}_{3}$ production occurs through the association of $\mathrm{OH}$ with $\mathrm{NO}_{2}$ (Reaction R7). $\mathrm{RONO}_{2}$ compounds are produced as a minor channel of the $\mathrm{RO}_{2}+\mathrm{NO}$ reaction. While the $\mathrm{RO}_{2}+\mathrm{NO}$ reaction typically produces $\mathrm{NO}_{2}$ and leads to the production of ozone (Reaction $\mathrm{R} 4 \mathrm{~b}$ ), for a small fraction of the time these two radicals will instead associate to form an organic nitrate (Reaction R4a).

The branching ratio $k_{\mathrm{R} 4 \mathrm{~b}} /\left(k_{\mathrm{R} 4 \mathrm{a}}+k_{\mathrm{R} 4 \mathrm{~b}}\right)$ is designated $\alpha$ and is determined by the nature of the $\mathrm{R}$ group as well as the temperature and pressure. Longer carbon backbones and lower temperatures increase $\alpha$, while lower pressures and oxygenated functional groups decrease it (Wennberg et al., 2018). Typical values of $\alpha$ in the summertime continental boundary layer range from near 0 for small hydrocarbons and highly oxygenated compounds to over 0.20 for large alkanes and alkenes (Perring et al., 2013).

$$
\begin{aligned}
& \mathrm{OH}+\mathrm{NO}_{2}+M \rightarrow \mathrm{HNO}_{3}+M, \\
& \mathrm{RO}_{2}+\mathrm{NO}+M \stackrel{\alpha}{\rightarrow} \mathrm{RONO}_{2}+M .
\end{aligned}
$$

The total rate of $\mathrm{RONO}_{2}$ production can be calculated from the properties of individual VOCs measured in the atmosphere via Eq. (1). In Eq. (1), $Y_{\mathrm{RO}_{2 i}}$ represents the yield of $\mathrm{RO}_{2}$ radicals from $\mathrm{VOC}$ oxidation and $f_{\mathrm{NO}_{i}}$ represents the fraction of those $\mathrm{RO}_{2}$ radicals that react with $\mathrm{NO}$ instead of reacting with $\mathrm{HO}_{2}$ or undergoing unimolecular isomerization (e.g., Teng et al., 2017). $f_{\mathrm{NO}_{i}}$ is close to 1 under polluted or moderately polluted conditions but decreases as the concentration of $\mathrm{NO}_{x}$ decreases.

$$
P\left(\mathrm{RONO}_{2}\right)=[\mathrm{OH}] \sum_{R_{i}}\left[R_{i}\right] \cdot k_{\mathrm{OH}+R_{i}} \cdot Y_{\mathrm{RO}_{2 i}} \cdot f_{\mathrm{NO}_{i}} \cdot \alpha_{i}
$$

If the contributions from individual VOCs are summed and averaged, the total production of $\mathrm{RONO}_{2}$ can also be calculated from the effective behavior of the VOC mixture via Eq. (2), where VOCR is the sum of all measured VOC concentrations weighted by their reaction rate with $\mathrm{OH}$.

$$
P\left(\mathrm{RONO}_{2}\right)=[\mathrm{OH}] \cdot \mathrm{VOCR} \cdot Y_{\mathrm{RO}_{2 \text { eff }}} \cdot f_{\mathrm{NO}_{\text {eff }}} \cdot \alpha_{\text {eff }}
$$

In a similar fashion, the production of $\mathrm{HNO}_{3}$ can be calculated via Eq. (3), where $\mathrm{NO} 2 \mathrm{R}$ is the $\mathrm{NO}_{2}$ reactivity, or the concentration of $\mathrm{NO}_{2}$ multiplied by $k_{\mathrm{OH}+\mathrm{NO}_{2}}$. At $298 \mathrm{~K}$ and $1 \mathrm{~atm}, 10 \mathrm{ppb}$ of $\mathrm{NO}_{2}$ is equivalent to an $\mathrm{NO} 2 \mathrm{R}$ of $2.3 \mathrm{~s}^{-1}$.

$$
P\left(\mathrm{HNO}_{3}\right)=[\mathrm{OH}] \cdot\left[\mathrm{NO}_{2}\right] \cdot k_{\mathrm{OH}+\mathrm{NO}_{2}}=[\mathrm{OH}] \cdot \mathrm{NO} 2 \mathrm{R}
$$

Total $\mathrm{NO}_{x}$ loss is the sum of the conversion to $\mathrm{HNO}_{3}$ and conversion to $\mathrm{RONO}_{2}$. The fraction of $\mathrm{NO}_{x}$ loss via $\mathrm{RONO}_{2}$ production can be expressed analytically as Eq. (4).

$$
\begin{aligned}
& \frac{P\left(\mathrm{RONO}_{2}\right)}{P\left(\mathrm{RONO}_{2}\right)+P\left(\mathrm{HNO}_{3}\right)} \\
& =\left(1+\frac{1}{\alpha_{\mathrm{eff}} \cdot f_{\mathrm{NO}_{\text {eff }}} \cdot Y_{\mathrm{RO}_{2} \text { eff }}} \times \frac{\mathrm{NO} 2 \mathrm{R}}{\mathrm{VOCR}}\right)^{-1}
\end{aligned}
$$

The relative production of $\mathrm{RONO}_{2}$ and $\mathrm{HNO}_{3}$ is seen to be controlled by two factors: the first describing the chemistry of $\mathrm{RO}_{2}$ radicals $\left(\alpha_{\text {eff }}, f_{\mathrm{NO}_{\text {eff }}}, Y_{\mathrm{RO}_{2 \text { eff }}}\right)$ and the second the ratio of NO2R to VOCR, which describes whether $\mathrm{OH}$ is more likely to react with a VOC or with $\mathrm{NO}_{2}$. Because Eq. (4) concerns fractional loss of $\mathrm{NO}_{x}$, the concentration of $\mathrm{OH}$, which affects $\mathrm{RONO}_{2}$ and $\mathrm{HNO}_{3}$ production equally, does not appear in the result.

We show below that in the summertime continental boundary layer, the terms describing $\mathrm{RO}_{2}$ radical chemistry vary significantly less than the NO2R/VOCR ratio, allowing the relative importance of $\mathrm{RONO}_{2}$ and $\mathrm{HNO}_{3}$ chemistry to be roughly estimated from only a single ratio.

\section{Observed contributions of $\mathrm{HNO}_{3}$ and $\mathrm{RONO}_{2}$ chemistry to $\mathrm{NO}_{x}$ loss}

\subsection{Daytime chemistry}

Relative $\mathrm{RONO}_{2}$ and $\mathrm{HNO}_{3}$ production rates were calculated for 13 separate campaign deployments in the Northern Hemisphere over the past 20 years. Campaigns were selected that included measurements of $\mathrm{NO}_{x}, \mathrm{HNO}_{3}, \mathrm{O}_{3}$, $\mathrm{HCHO}$, a wide range of VOCs, and total organic nitrates $\left(\Sigma \mathrm{RONO}_{2}\right)$. Although they do not include measurements of $\Sigma \mathrm{RONO}_{2}$, ITCT2k2 and CALNEX-P3 were also included to provide a pair of measurements of VOCs and $\mathrm{NO}_{x}$ in the same geographic location separated in time. A list of all campaigns used in this study is given in Table 1 . Where available, measurements of $\mathrm{OH}$ and $\mathrm{HO}_{2}$ were used to directly calculate $\mathrm{RO}_{2}$ formation and loss. When these radicals were not available, $\mathrm{OH}$ and $\mathrm{HO}_{2}$ radical concentrations were also calculated iteratively based on the total rate of $\mathrm{HO}_{x}$ radical production by $\mathrm{O}_{3}$ photolysis, $\mathrm{HCHO}$ photolysis, and alkene ozonolysis. When HONO was measured, HONO photolysis was also included as an $\mathrm{OH}$ source. In a small fraction of cases (3\% of all data points), NO measurements were not available and $\mathrm{NO}$ concentrations were calculated based on the concentrations of $\mathrm{O}_{3}$ and $\mathrm{NO}_{2}$. Details of the radical modeling, including the equations used to calculate the production and loss of these radicals, are given in Appendix A.

Although these field campaigns do not constitute a random sample of the atmosphere, the combined dataset provides an excellent survey of atmospheric chemistry over a wide range of conditions. The combined dataset includes nearly 8000 data points for which fractional $\mathrm{NO}_{x}$ loss can be calculated, spanning nearly 3 orders of magnitude in the ratio of NO2R to VOCR with no significant gaps (Fig. 2). 
Table 1. Field campaigns used in this analysis

\begin{tabular}{|c|c|c|c|c|c|}
\hline Campaign name & Data reference & Format & Year & Base of operations & Date \\
\hline ITCT2k2 & ITCT Science Team (2002) & Airborne & 2002 & Monterey, CA, USA & 22 Apr-19 May \\
\hline INTEX-NA & INTEX-A Science Team (2006) & Airborne & 2004 & $\begin{array}{l}\text { Palmdale, CA, USA } \\
\text { Mascoutah, IL, USA } \\
\text { Portsmouth, NH, USA } \\
\text { Mascoutah, IL, USA }\end{array}$ & $\begin{array}{l}2 \text { Jul } \\
7-14 \text { Jul } \\
16 \text { Jul-10 Aug } \\
12 \text { Aug }\end{array}$ \\
\hline INTEX-B & INTEX-B Science Team (2011) & Airborne & 2006 & $\begin{array}{l}\text { Houston, TX, USA } \\
\text { Honolulu, HI, USA } \\
\text { Anchorage, AK, USA }\end{array}$ & $\begin{array}{l}\text { 4-19 Mar } \\
23-28 \mathrm{Apr} \\
1-12 \mathrm{May}\end{array}$ \\
\hline BEARPEX 2007 & BEARPEX 07 Science Team (2007) & Ground & 2007 & Georgetown, CA, USA & 15 Aug-10 Oct \\
\hline ARCTAS-B & ARCTAS-B Science Team (2011) & Airborne & 2008 & $\begin{array}{l}\text { Palmdale, CA, USA } \\
\text { Cold Lake, Alberta, Canada } \\
\text { Thule, Greenland }\end{array}$ & $\begin{array}{l}\text { 18-24 Jun } \\
29 \text { Jun-8 Jul } \\
8-10 \text { Jul }\end{array}$ \\
\hline BEARPEX 2009 & BEARPEX 09 Science Team (2009) & Ground & 2009 & Georgetown, CA, USA & 15 Jun-31 Jul \\
\hline CALNEX-P3 & CALNEX Science Team (2002a) & Airborne & 2010 & Ontario, CA, USA & 1 May-22 Jun \\
\hline CALNEX-SJV & CALNEX Science Team (2002b) & Ground & 2010 & Bakersfield, CA, USA & 15 May-30 Jun \\
\hline DC3 & DC3 Science Team (2013) & Airborne & 2012 & Salina, KS, USA & 13 May-30 Jun \\
\hline SOAS & SOAS Science Team (2013) & Ground & 2013 & Centreville, AL, USA & 1 Jun-15 Jul \\
\hline SEAC4RS & SEAC4RS Science Team (2014) & Airborne & 2013 & Houston, TX, USA & 8 Aug-23 Sep \\
\hline FRAPPÉ & FRAPPÉ Science Team (2014) & Airborne & 2014 & Broomfield, CO, USA & 16 Jul-16 Aug \\
\hline KORUS-AQ & KORUS-AQ Science Team (2018) & Airborne & 2016 & $\begin{array}{l}\text { Pyeongtaek, South Korea } \\
\text { Palmdale, CA, USA }\end{array}$ & $\begin{array}{l}1 \text { May-14 Jun } \\
17 \text { Jun-18 Jun }\end{array}$ \\
\hline
\end{tabular}

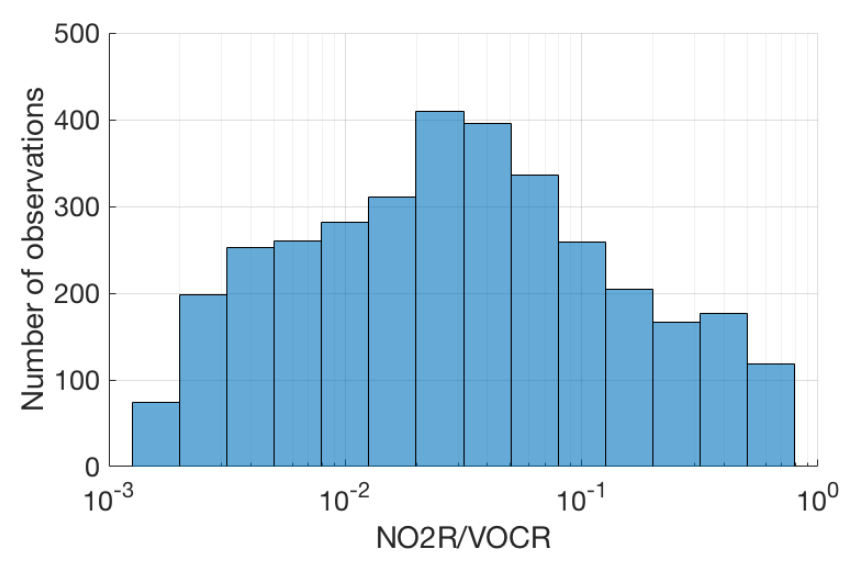

Figure 2. Number of points in each bin for which the fraction of $\mathrm{NO}_{x}$ loss occurring via $\mathrm{RONO}_{2}$ chemistry could be calculated.

The fraction of total $\mathrm{NO}_{x}$ loss occurring via $\mathrm{RONO}_{2}$ chemistry from all 13 of these campaigns is shown in Fig. 3a for points within the continental summertime boundary layer. Despite spanning a large range of environments, all 13 campaigns are well described by a single function of the form $\left(1+b \cdot\left(\frac{\mathrm{NO} 2 \mathrm{R}}{\mathrm{VOCR}}\right)^{m}\right)^{-1}$ (red line in Fig. 3a). This functional form corresponds to a linear relationship between $P\left(\mathrm{RONO}_{2}\right) / P\left(\mathrm{HNO}_{3}\right)$ and $\mathrm{NO} 2 \mathrm{R} / \mathrm{VOCR}$ on a log$\log$ scale. If $m$ is fixed to 1 , then this form also corresponds to the expected behavior if the VOC mixture did not change between environments, and so all parameters other than NO2R/VOCR remained constant (gray line in Fig. 3a).

The calculated increase in fractional $\mathrm{NO}_{x}$ loss via $\mathrm{RONO}_{2}$ chemistry as NO2R/VOCR decreases is matched by an increase in the observed ratio of $\Sigma \mathrm{RONO}_{2}$ to the sum of $\Sigma \mathrm{RONO}_{2}$ and $\mathrm{HNO}_{3}$ (Fig. 3b). However, the increase in fractional concentrations as NO2R/VOCR decreases is much less than the increase in fractional production. At low $\mathrm{NO} 2 \mathrm{R} / \mathrm{VOCR}$ ratios, the dominant $\mathrm{RONO}_{2}$ species are typically short lived and can undergo heterogeneous hydrolysis to produce $\mathrm{HNO}_{3}$ (e.g., Browne et al., 2013). This indirect source of $\mathrm{HNO}_{3}$ can be the greatest source of $\mathrm{HNO}_{3}$ in forested environments, and it leads to the relatively weak dependence of fractional concentration on NO2R/VOCR.

While the fraction of $\mathrm{NO}_{x}$ loss occurring via $\mathrm{RONO}_{2}$ chemistry can be well predicted from just the NO2R/VOCR ratio, the observations exhibit a sharper transition from $\mathrm{HNO}_{3}$-dominated to $\mathrm{RONO}_{2}$-dominated $\mathrm{NO}_{x}$ loss than 

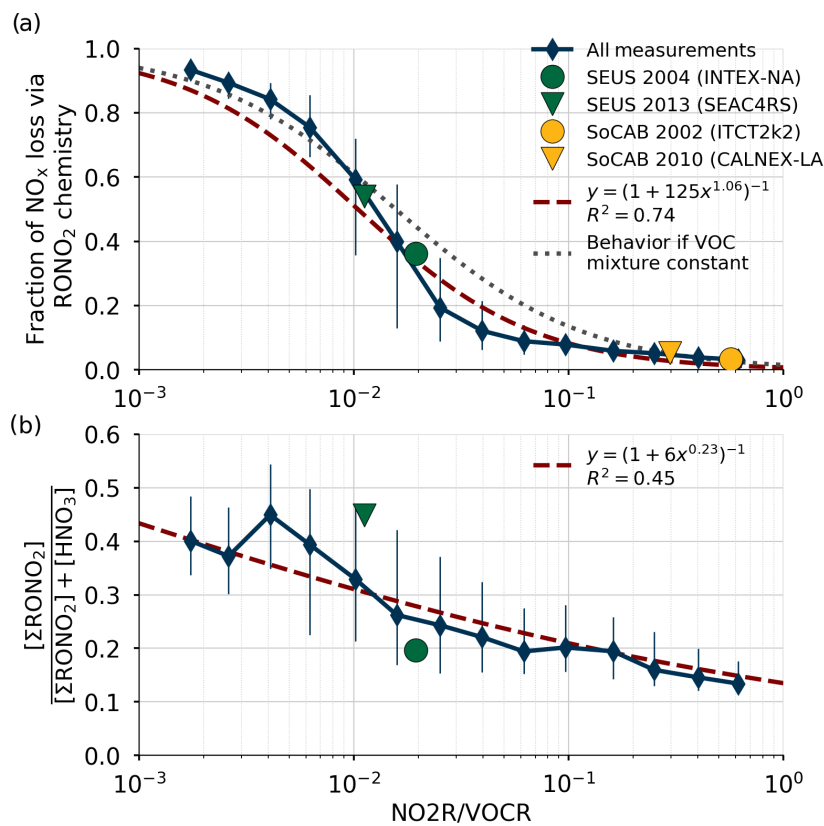

Figure 3. Comparison of the relative production rates of $\mathrm{RONO}_{2}$ and $\mathrm{HNO}_{3}$ as a function of $\mathrm{NO} 2 \mathrm{R} / \mathrm{VOCR}$. Used data points are restricted to the continental summer daytime boundary layer (i.e., over land, less than $1.5 \mathrm{~km}$ above ground level, and average temperature $>10^{\circ} \mathrm{C}$ ). Panel (a) shows the fraction of $\mathrm{NO}_{x}$ loss attributable to $\mathrm{RONO}_{2}$ chemistry, as well as a least-squares fit to the data and the expected behavior if $\alpha_{\text {eff }}, f_{\mathrm{NO}_{\text {eff }}}$, and $Y_{\mathrm{RO}_{2} \text { eff }}$ were constant. Panel (b) shows the ratio of $\Sigma \mathrm{RONO}_{2}$ to the sum of $\mathrm{HNO}_{3}$ and $\Sigma \mathrm{RONO}_{2}$. In each panel, the blue diamonds show the median in each bin, and the vertical lines show the interquartile range.

would be expected if the VOC mixture remained constant. This effect can be explained by variation in $Y_{\mathrm{RO}_{2 \text { eff }}}, \alpha_{\text {eff }}$, and $f_{\mathrm{NO}_{\text {eff }}}$ as NO2R/VOCR changes. The behavior of these three parameters is shown in Fig. 4. As NO2R/VOCR decreases, $f_{\mathrm{NO}_{\text {eff }}}$ consistently decreases from 0.8 to 0.2 , due almost entirely to the decrease in $\mathrm{NO}_{x}$ concentrations. In contrast, both $Y_{\mathrm{RO}_{2 \text { eff }}}$ and $\alpha_{\text {eff }}$ are larger in areas with low NO2R/VOCR ratios, due to changes in the VOC mixture between environments. In areas where NO2R/VOCR is high, many of the predominant VOCs, including $\mathrm{CO}, \mathrm{HCHO}$, and aromatics, either do not produce $\mathrm{RO}_{2}$ radicals when oxidized by $\mathrm{OH}$ or produce $\mathrm{RO}_{2}$ radicals that do not efficiently produce organic nitrates, leading to the relatively low values of $Y_{\mathrm{RO}_{2} \text { eff }}$

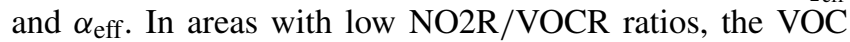
mixture is often dominated by biogenic alkenes such as isoprene and monoterpenes that efficiently produce organic nitrates, leading to higher values of both $Y_{\mathrm{RO}_{2 \text { eff }}}$ and $\alpha_{\text {eff. }}$. However, although variation in these parameters can help explain some of the observed behavior of fractional $\mathrm{NO}_{x}$ loss, the overall variation is much smaller than the variation of the $\mathrm{NO} 2 \mathrm{R} / \mathrm{VOCR}$ ratio. Each of the three parameters varies by a factor of 4 or less, while the NO2R/VOCR ratio varies by a factor of 1000 .

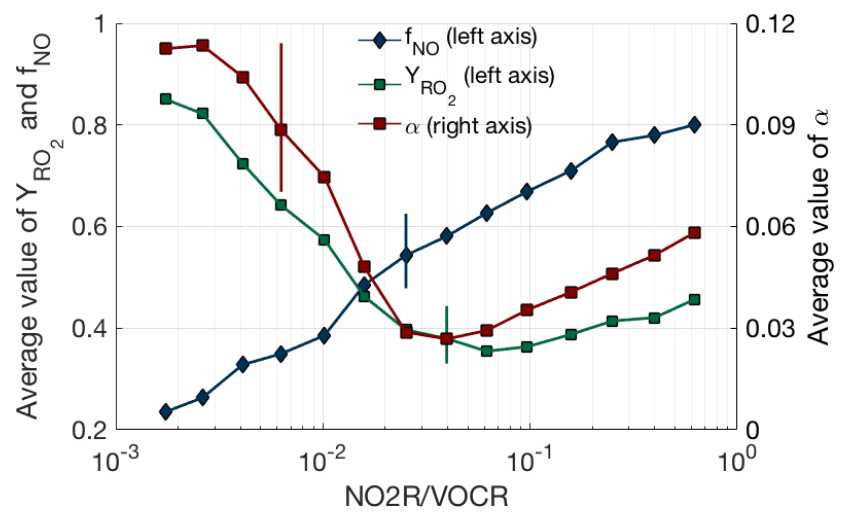

Figure 4. VOC oxidation parameters $\left(\alpha_{\mathrm{eff}}, f_{\mathrm{NO}_{\mathrm{eff}}}, Y_{\mathrm{RO}_{2 \mathrm{eff}}}\right)$ as a function of $\mathrm{NO} 2 \mathrm{R} / \mathrm{VOCR}$. Used data points are restricted to the continental summer daytime boundary layer (i.e., over land, less than $1.5 \mathrm{~km}$ above ground level, and average temperature $>10^{\circ} \mathrm{C}$ ). The line and solid shapes show the median in each bin, and the vertical lines show an example of the interquartile range for each binned parameter.

The conclusion that variation in VOC parameters is small compared to the variation in the NO2R/VOCR ratio does not hold outside of the summertime continental boundary layer. In the remote marine boundary layer or in the upper troposphere, $\alpha_{\text {eff }}$ is extremely low, as the dominant VOCs produce alkyl nitrates at yields of 0.01 or less (Mao et al., 2009; Perring et al., 2013). Under these conditions, $\mathrm{HNO}_{3}$ dominates $\mathrm{NO}_{x}$ loss even when NO2R/VOCR is less than $3 \times 10^{-2}$.

The trend calculated from the in situ observations matches that found in model simulations: in areas with high ratios of $\mathrm{NO} 2 \mathrm{R}$ to VOCR, $\mathrm{HNO}_{3}$ is the dominant $\mathrm{NO}_{x}$ sink, but as concentrations of $\mathrm{NO}_{x}$ decrease and concentrations of VOCs increase, the opposite is true. The combined in situ observations show that the importance of $\mathrm{RONO}_{2}$ chemistry to $\mathrm{NO}_{x}$ loss is a nonlinear function of the NO2R/VOCR ratio, leading to a sharp transition between the $\mathrm{HNO}_{3}$-dominated and $\mathrm{RONO}_{2}$-dominated regimes. The sharp transition suggests there is a strong gradient in chemical $\mathrm{NO}_{x}$ loss between urban and rural areas, especially in areas with significant biogenic VOC emissions. Furthermore, the sharp transition indicates that some regions may quickly shift from $\mathrm{HNO}_{3}-$ dominated to $\mathrm{RONO}_{2}$-dominated regimes if $\mathrm{NO} 2 \mathrm{R} / \mathrm{VOCR}$ decreases.

\subsection{Nighttime chemistry}

While the primary focus of this analysis is on daytime chemistry, a conceptually similar transition may also occur at night. At night, $\mathrm{OH}$ concentrations are near zero, and the first step in $\mathrm{NO}_{x}$ oxidation is the reaction of $\mathrm{NO}_{2}$ with $\mathrm{O}_{3}$ to produce $\mathrm{NO}_{3}$. This radical can in turn react either with $\mathrm{NO}_{2}$ to form $\mathrm{N}_{2} \mathrm{O}_{5}$ or with an alkene to form an organic nitrate 
(Reactions R8-R9).

$\mathrm{NO}_{3}+\mathrm{RH} \rightarrow \mathrm{RONO}_{2}$,

$\mathrm{NO}_{3}+\mathrm{NO}_{2} \rightleftharpoons \mathrm{N}_{2} \mathrm{O}_{5}$.

Finally, $\mathrm{N}_{2} \mathrm{O}_{5}$ can either thermally decompose to re-form $\mathrm{NO}_{3}$ and $\mathrm{NO}_{2}$ or it can hydrolyze on aerosol surfaces to produce $\mathrm{HNO}_{3}$ (Reactions R9-R10).

$\mathrm{N}_{2} \mathrm{O}_{5} \stackrel{k_{\text {hyd }}}{\longrightarrow} 2 \mathrm{HNO}_{3}$

Although the details are different, the nighttime chemical system shares some fundamental similarities with the daytime system: $\mathrm{NO}_{x}$ can be lost through the production of $\mathrm{RONO}_{2}$ or of $\mathrm{HNO}_{3}$, and a key step controlling the relative importance of these two sinks is whether an oxidant reacts with $\mathrm{NO}_{2}$ or with a VOC. These similarities suggest that the relative importance of $\mathrm{RONO}_{2}$ and $\mathrm{HNO}_{3}$ as $\mathrm{NO}_{x}$ sinks at night may be controlled by the relative reactivities of $\mathrm{NO}_{2}$ and VOCs towards $\mathrm{NO}_{3}$. In areas where $\mathrm{NO}_{3}$ is more likely to react with $\mathrm{NO}_{2}, \mathrm{HNO}_{3}$ production is likely to dominate $\mathrm{NO}_{x}$ loss, while the opposite is likely to be true in areas where $\mathrm{NO}_{3}$ is more likely to react with a VOC.

However, quantitatively estimating the relative fraction of $\mathrm{NO}_{x}$ lost through these different pathways is not practical with the combined dataset presented here. There have been relatively few measurements of the nocturnal atmosphere (only 4 of the 13 campaigns in Table 1 include nighttime measurements) and there remain significant uncertainties in the kinetics of nighttime $\mathrm{NO}_{x}$ loss. In particular, the overall rate of $\mathrm{N}_{2} \mathrm{O}_{5}$ hydrolysis is controlled by the reactive uptake parameter $\gamma$ and the aerosol surface area, both of which can vary by multiple orders of magnitude (Brown et al., 2009; McDuffie et al., 2018). Variation in the rate of $\mathrm{N}_{2} \mathrm{O}_{5}$ hydrolysis may therefore also play a major role in controlling the relative importance of $\mathrm{RONO}_{2}$ and $\mathrm{HNO}_{3}$ chemistry to $\mathrm{NO}_{x}$ loss at night. While developing a more quantitative understanding of the trends in the chemical mechanisms of nocturnal $\mathrm{NO}_{x}$ loss is an important area for future research, the conceptual similarity between the daytime and nighttime regimes suggests that conclusions based on daytime $\mathrm{NO}_{x}$ chemistry may also be relevant to the nighttime.

\section{Predicted trends over time}

Using the trends in Fig. 3a to understand trends in $\mathrm{NO}_{x}$ chemistry over time is only possible if the response to variation across space is equivalent to the response to variation across time. Two direct comparisons of fractional $\mathrm{NO}_{x}$ loss in the same environment but at different times are found to fall along the same curve as the variation between campaigns in different locations (Fig. 3), indicating that such a substitution is valid in this analysis. The first case, INTEX-NA and SEAC4RS, sampled the southeast United States (SEUS) in

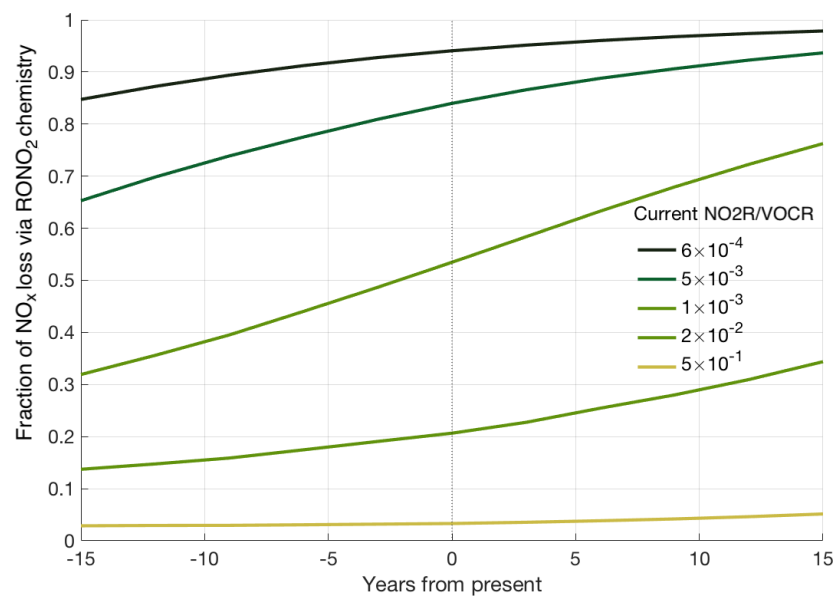

Figure 5. Predicted trends in fractional $\mathrm{NO}_{x}$ loss over time, calculated from the estimated NO2R/VOCR ratio assuming a constant $6.5 \% \mathrm{yr}^{-1}$ decrease in anthropogenic VOC concentrations, a $5.5 \% \mathrm{yr}^{-1}$ decrease in $\mathrm{NO}_{x}$ concentrations, and a $1.5 \% \mathrm{yr}^{-1}$ increase in biogenic VOC concentrations.

2004 and 2013; the second case, ITCT2k2 and CALNEXP3, sampled the South Coast Air Basin (SoCAB) around Los Angeles in 2002 and 2010. Averages from these pairs of campaigns are shown in Fig. 3a and all four points fall along the same overall curve. For INTEX-NA and SEAC4RS, the shift in chemistry towards the $\mathrm{RONO}_{2}$-dominated regime is accompanied by a dramatic shift in the ratio of $\Sigma \mathrm{RONO}_{2}$ and $\mathrm{HNO}_{3}$ concentrations, where $\Sigma \mathrm{RONO}_{2}$ concentrations were only one-quarter of $\mathrm{HNO}_{3}$ in 2004 but were nearly equal to $\mathrm{HNO}_{3}$ in 2013. $\Sigma \mathrm{RONO}_{2}$ measurements are not available for ITCT2k2 or CALNEX-P3, preventing a similar comparison from being made for those campaigns.

Together, these cases indicate that the trend from Fig. 3a can be used to predict changes in fractional loss if the trend in NO2R/VOCR is known. Over the past decade, satellite measurements of $\mathrm{NO}_{2}$ show a significant decrease in national $\mathrm{NO}_{2}$ concentrations, reporting an average decrease of 4.5\%-7\% per year between 2005 and 2011 (Russell et al., 2012). No comparable satellite observations of VOCs exist, but studies in multiple locations have reported a decrease in primary anthropogenic VOC concentrations of 5.5\%-7.5\% per year over 2000-2010 (Geddes et al., 2009; Warneke et al., 2012; Pollack et al., 2013; Pusede et al., 2014). In contrast, biogenic VOC concentrations have been either constant or increasing over that same time period (Geddes et al., 2009; Hidy et al., 2014). Oxygenated VOCs show no major trend with time, although there are few long-term measurements of these species (Geddes et al., 2009; Pusede et al., 2014).

These varied trends in $\mathrm{NO}_{x}$, anthropogenic VOCs, and biogenic VOCs mean that NO2R/VOCR has not changed uniformly over the past decade. Past NO2R/VOCR ratios were calculated by assuming a $6.5 \% \mathrm{yr}^{-1}$ decrease to anthropogenic VOC concentrations, a $5.5 \% \mathrm{yr}^{-1}$ decrease to 
$\mathrm{NO}_{x}$ concentrations, and a $1.5 \% \mathrm{yr}^{-1}$ increase in biogenic VOC concentrations over the past 15 years. We also extrapolate these same trends to estimate NO2R/VOCR 15 years into the future. The calculated NO2R/VOCR ratios are combined with the relationship from Fig. 3 to estimate fractional $\mathrm{NO}_{x}$ loss at different times (Fig. 5). Based on these trends, $\mathrm{RONO}_{2}$ chemistry is seen to have become a larger portion of total $\mathrm{NO}_{x}$ loss over the past 15 years, although the change is not evenly distributed. The similar trends in $\mathrm{NO}_{x}$ and anthropogenic VOCs cause there to have been little to no change in the regions with the highest NO2R/VOCR ratios (typically large cities). The largest changes are projected to occur in regions with moderate NO2R/VOCR ratios. In these regions, biogenic VOCs often account for a greater fraction of the VOCR, leading to significant decreases in NO2R/VOCR over the past 15 years. In addition, the response of fractional $\mathrm{NO}_{x}$ loss to changes in the NO2R/VOCR ratio is magnified in areas where both $\mathrm{RONO}_{2}$ and $\mathrm{HNO}_{3}$ chemistry contribute to $\mathrm{NO}_{x}$ loss. In this transitional regime, if recent trends continue, the fraction of $\mathrm{NO}_{x}$ loss occurring via $\mathrm{RONO}_{2}$ chemistry could double in the next 15 years. Given the large number of data points sampled in this transition regime (Fig. 2), many regions of the United States are therefore likely to transition from a regime where $\mathrm{HNO}_{3}$ dominates $\mathrm{NO}_{x}$ loss to a mixed or $\mathrm{RONO}_{2}$-dominated regime.

\section{Impacts of the transition from the $\mathrm{HNO}_{3}$ to the $\mathrm{RONO}_{2}$ regime}

The growing importance of $\mathrm{RONO}_{2}$ chemistry to $\mathrm{NO}_{x}$ loss has several implications for air quality. Most directly, it means that understanding $\mathrm{NO}_{x}$ chemistry in all but the most polluted megacities requires including the effects of $\mathrm{RONO}_{2}$ chemistry. More theoretically, the transition from $\mathrm{HNO}_{3}$ - to $\mathrm{RONO}_{2}$-dominated $\mathrm{NO}_{x}$ loss affects how atmospheric chemistry will respond to changes in emissions of $\mathrm{NO}_{x}$ and VOCs. Because $\mathrm{RONO}_{2}$ species are produced in the same set of reactions that produce $\mathrm{O}_{3}$, the fractional loss of $\mathrm{NO}_{x}$ via $\mathrm{RONO}_{2}$ chemistry is directly proportional to the ozone production efficiency (OPE), the ratio of ozone production to $\mathrm{NO}_{x}$ loss (Eq. 5).

$$
\begin{aligned}
& \mathrm{OPE}=\frac{P\left(\mathrm{O}_{3}\right)}{L\left(\mathrm{NO}_{x}\right)}=\frac{2 \cdot \mathrm{VOCR} \cdot Y_{\mathrm{RO}_{2 \mathrm{eff}}} \cdot f_{\mathrm{NO}_{\text {eff }}} \cdot\left(1-\alpha_{\mathrm{eff}}\right)}{\mathrm{NO} 2 \mathrm{R}+\mathrm{VOCR} \cdot Y_{\mathrm{RO}_{2 \mathrm{eff}}} \cdot f_{\mathrm{NO}_{\mathrm{eff}}} \cdot \alpha_{\mathrm{eff}}} \\
& \propto \frac{P\left(\mathrm{RONO}_{2}\right)}{P\left(\mathrm{RONO}_{2}\right)+P\left(\mathrm{HNO}_{3}\right)}
\end{aligned}
$$

Fundamentally, OPE represents the total amount of ozone produced for each molecule of $\mathrm{NO}_{x}$ emitted. When considering ozone pollution on regional scales, OPE is a more appropriate metric than instantaneous ozone production, because it accounts for ozone production both locally and further afield.

Figure 6 uses the theoretic framework described in Romer et al. (2018) to investigate how ozone and $\mathrm{NO}_{x}$ chemistry change as a function of NO2R/VOCR. As the NO2R/VOCR
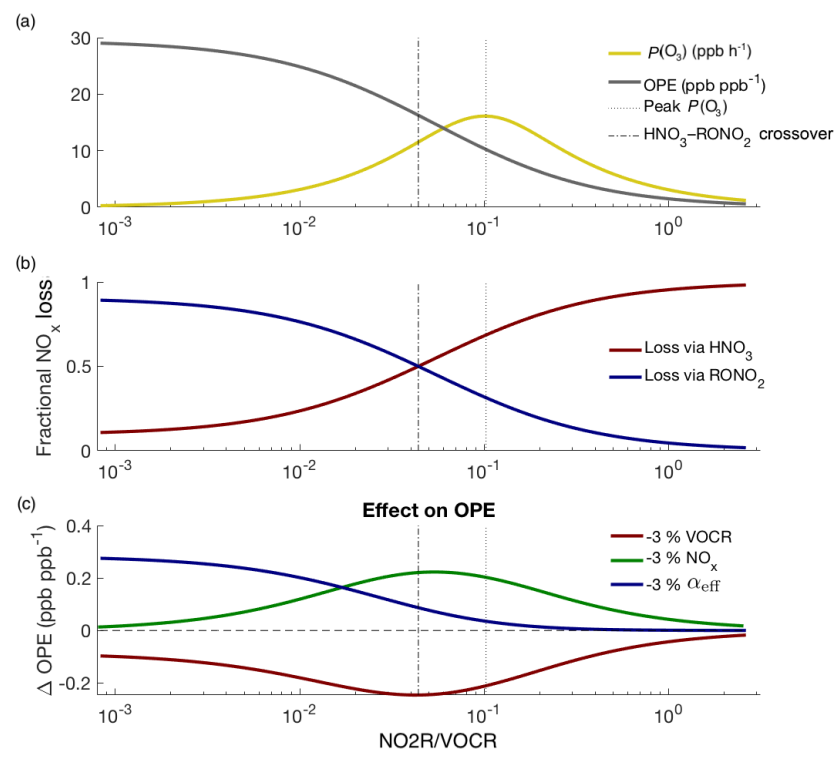

Figure 6. Theoretical picture of $\mathrm{NO}_{x}$ and $\mathrm{O}_{3}$ chemistry, calculated using variable $\mathrm{NO}_{x}$ concentrations and fixed VOCR, $P\left(\mathrm{HO}_{x}\right)$,

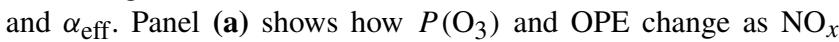
changes; panel (b) shows how the fractional $\mathrm{NO}_{x}$ loss changes as NO2R/VOCR decreases; panel (c) shows that changes to $\mathrm{NO}_{x}$ and VOCR have their greatest effect on OPE not when $P\left(\mathrm{O}_{3}\right)$ is at a maximum, but at the crossover point between the $\mathrm{RONO}_{2}$ dominated and $\mathrm{HNO}_{3}$-dominated regimes.

ratio decreases, OPE increases, reaching an inflection point exactly at the crossover point between the $\mathrm{HNO}_{3}$-dominated and $\mathrm{RONO}_{2}$-dominated regimes (Fig. 6a-b). For the polluted areas of the country, where $\mathrm{HNO}_{3}$ is currently the dominant $\mathrm{NO}_{x}$ loss pathway, this means that, for example, interventions to improve air quality by reducing $\mathrm{NO}_{x}$ emissions will be fighting uphill because every incremental fractional decrease in $\mathrm{NO}_{x}$ emissions will be associated with a growing incremental increase in OPE (Fig. 6c).

In addition, as $\mathrm{RONO}_{2}$ chemistry becomes a more important part of the $\mathrm{NO}_{x}$ budget, changes to $\alpha_{\text {eff }}$ have an increasing effect on OPE (Fig. 6c). Policy interventions that reduce VOCR but preferentially target high- $\alpha$ compounds (e.g., long-chain alkanes) could inadvertently increase ozone production or OPE (Farmer et al., 2011; Perring et al., 2013).

In addition to the large effects on aerosol yield that changes to $\mathrm{NO}_{x}$ and VOC emissions have directly (e.g., $\mathrm{Xu}$ et al., 2015a; Pusede et al., 2016), they also affect aerosols by changing the fate of $\mathrm{NO}_{x}$. While both $\mathrm{HNO}_{3}$ and $\mathrm{RONO}_{2}$ can form aerosols (Stelson and Seinfeld, 1982; Pye et al., 2015), the properties of the resulting aerosols are likely to differ. Because $\mathrm{HNO}_{3}$ is a strong acid, a shift towards $\mathrm{RONO}_{2}$ chemistry is likely to increase aerosol $\mathrm{pH}$. An increase in the role of $\mathrm{RONO}_{2}$ chemistry will also cause more of the nitrate aerosol to be organic rather than inorganic, potentially affecting the viscosity and morphology of aerosols. 

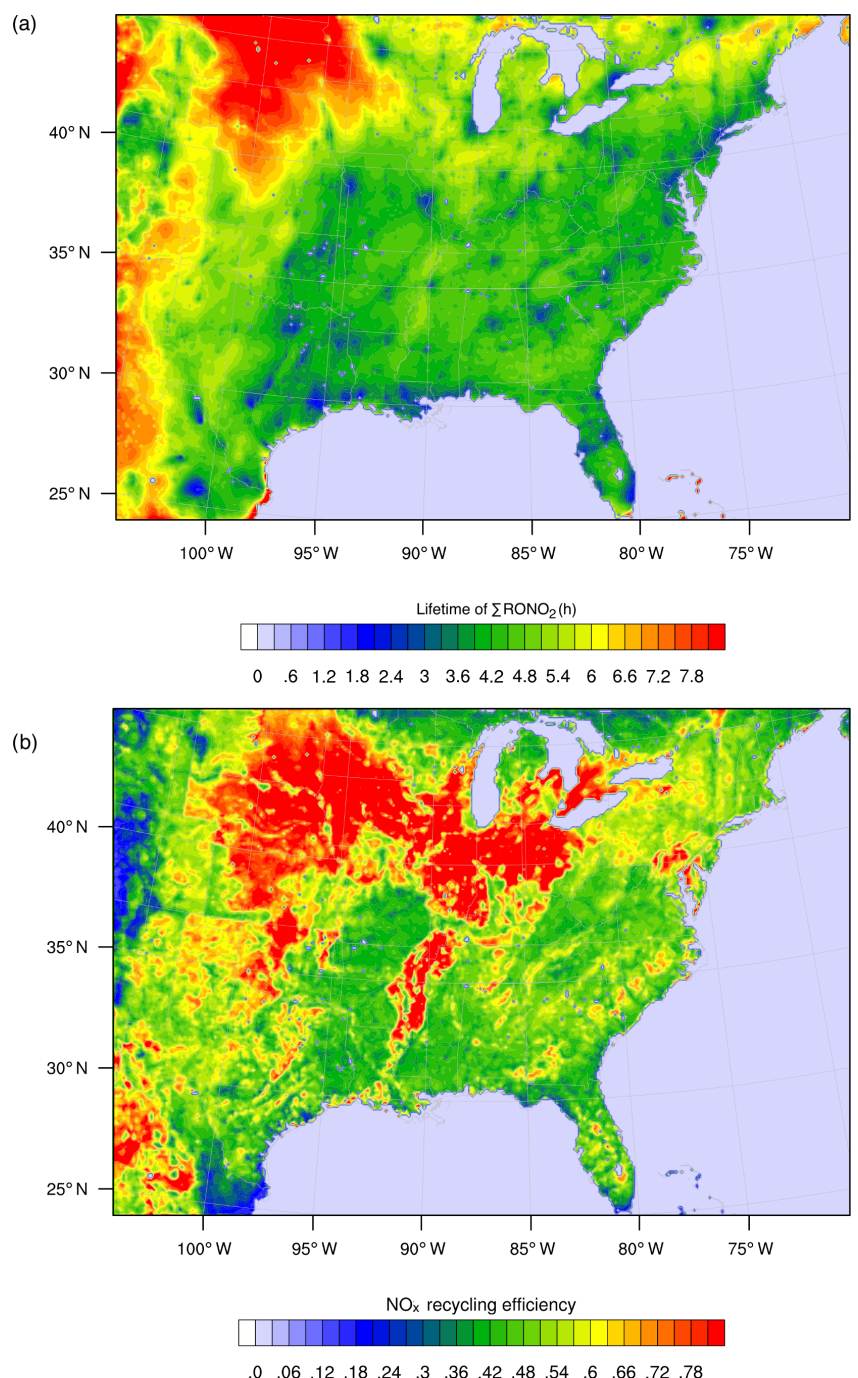

Figure 7. WRF-Chem simulation of $\mathrm{RONO}_{2}$ chemistry over the southeast United States for summer 2013 as described in Zare et al. (2018). Panel (a) shows the overall lifetime of $\Sigma \mathrm{RONO}_{2}$, defined as the concentration of $\Sigma \mathrm{RONO}_{2}$ divided by their chemical loss rate for the daytime boundary layer. Panel (b) shows the average $\mathrm{NO}_{x}$ recycling efficiency, defined as the local rate of $\mathrm{NO}_{x}$ production from $\mathrm{RONO}_{2}$ oxidation divided by the rate of $\mathrm{RONO}_{2}$ production.

Further effects of changing $\mathrm{NO}_{x}$ chemistry arise from the distinct fates of $\mathrm{RONO}_{2}$ and $\mathrm{HNO}_{3}$. Many $\mathrm{RONO}_{2}$ compounds, especially those derived from isoprene, are remarkably reactive in the troposphere, with lifetimes of a few hours or less. A fraction of this $\mathrm{RONO}_{2}$ loss returns $\mathrm{NO}_{x}$ to the atmosphere, allowing $\mathrm{RONO}_{2}$ production to effectively transport $\mathrm{NO}_{x}$ downwind (Romer et al., 2016; Xiong et al., 2016). In contrast, $\mathrm{HNO}_{3}$ is effectively chemically inert in the troposphere, with a chemical lifetime of $50 \mathrm{~h}$ or more.

As a result of the differing chemical fates and lifetimes, transitioning from a $\mathrm{HNO}_{3}$-dominated regime to a mixed or $\mathrm{RONO}_{2}$-dominated regime has implications for the distribu-

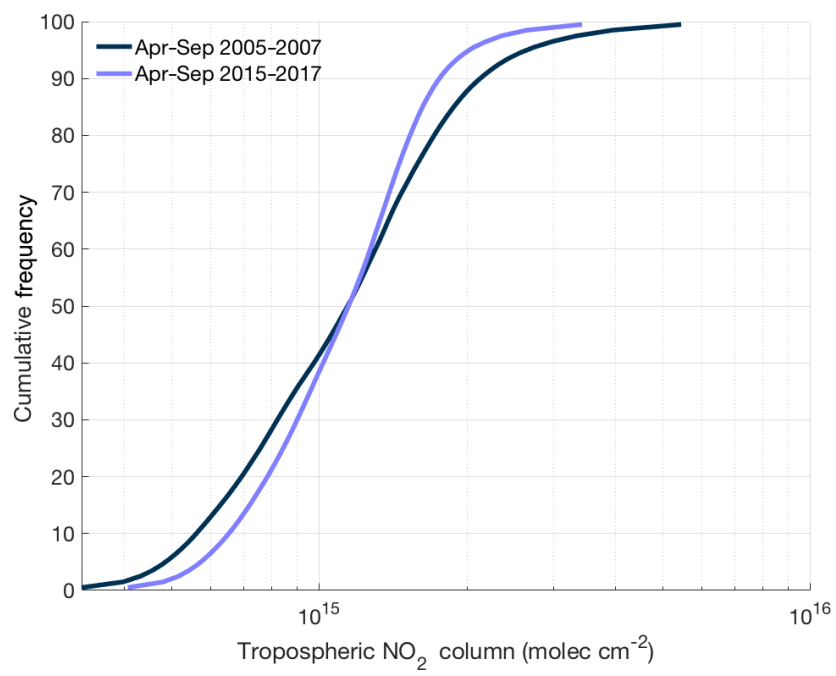

Figure 8. Cumulative frequency distribution of ozone monitoring instrument tropospheric $\mathrm{NO}_{2}$ columns over the continental United States using the BErkeley High-Resolution (BEHR) v3.0A retrieval for summer (April-September) in 2005-2007 and 2015-2017.

tion of $\mathrm{NO}_{x}$ on regional to continental scales. If a greater fraction of $\mathrm{NO}_{x}$ in polluted or moderately polluted regions is converted into $\mathrm{RONO}_{2}$ compounds rather than into $\mathrm{HNO}_{3}$, then more of the $\mathrm{NO}_{x}$ may be re-released downwind, where it can participate in radical chemistry and ozone production. Simulations of $\mathrm{RONO}_{2}$ chemistry using WRF-Chem and the RACM2_Berkeley2 mechanism (Zare et al., 2018) were used to investigate the $\mathrm{RONO}_{2}$ lifetime and $\mathrm{NO}_{x}$ recycling efficiency of $\mathrm{RONO}_{2}$ across the southeast United States in summer 2013 (Fig. 7). Across much of the region, $\Sigma \mathrm{RONO}_{2}$ is calculated to have a lifetime of roughly $4 \mathrm{~h}$, and the release of $\mathrm{NO}_{x}$ from $\mathrm{RONO}_{2}$ oxidation was between $40 \%$ and $75 \%$ of the instantaneous $\mathrm{RONO}_{2}$ production rate. Combined, these findings demonstrate a significant role for $\mathrm{RONO}_{2}$ chemistry in the transport of $\mathrm{NO}_{x}$ between regions in the southeast United States. The effects of organic nitrate chemistry on the distribution of $\mathrm{NO}_{x}$ is likely to vary greatly across different regions of the United States and should be studied in further detail.

Enhanced $\mathrm{NO}_{x}$ transport between source and receptor regions is one aspect of a combined trend that is transforming the spatial distribution of $\mathrm{NO}_{x}$. Over the past decade, $\mathrm{NO}_{x}$ emission reductions have been concentrated in the most polluted environments. In these areas, motor vehicles and power plants, targets of emission control strategies, account for almost all of the $\mathrm{NO}_{x}$ emissions. In less polluted regions, other sources of $\mathrm{NO}_{x}$, including soil microbes (both in agricultural and nonagricultural regions), off-road vehicles, fires, and lightning, play a greater role in the $\mathrm{NO}_{x}$ budget, reducing the effectiveness of typical combustion-related $\mathrm{NO}_{x}$ emission controls. In addition, hemispheric background concentrations of $\mathrm{NO}_{x}$ and $\mathrm{O}_{3}$ have risen slightly over the past 2 
decades (Cooper et al., 2012). The combination of all three of these trends suggests that the distribution of $\mathrm{NO}_{x}$ across the United States is getting flatter over time. This trend matches satellite observations of $\mathrm{NO}_{2}$ over the continental United States. Figure 8 shows the cumulative frequency distribution of summertime tropospheric $\mathrm{NO}_{2}$ columns from 20052007 and 2015-2017 using the BErkeley High-Resolution (BEHR) v3.0A retrieval (Laughner et al., 2018a) of slantcolumn measurements from ozone monitoring instrument (OMI). Over this time, the highest percentiles of $\mathrm{NO}_{2}$ concentrations have decreased and the lowest percentiles increased, leading to a significantly narrower distribution of $\mathrm{NO}_{2}$ concentrations.

In summary, over the past 15 years, decreases in anthropogenic $\mathrm{NO}_{x}$ and VOC emissions have led to a significant shift in the mechanisms of daytime $\mathrm{NO}_{x}$ loss. Many places where $\mathrm{HNO}_{3}$ production dominated $\mathrm{NO}_{x}$ loss are now mixed or have switched to a situation where the majority of $\mathrm{NO}_{x}$ loss occurs through $\mathrm{RONO}_{2}$ chemistry. If past trends continue, $\mathrm{RONO}_{2}$ chemistry will grow to become an even more important fraction of $\mathrm{NO}_{x}$ chemistry in coming decades. As a result of this combination of changing $\mathrm{NO}_{x}$ chemistry, decreasing $\mathrm{NO}_{x}$ emissions, and increasing background concentrations, air pollution in the United States may transform from a highly local issue to a more extended regional one. Efforts to control air pollution focused only on local sources are less likely to be effective; future improvements in air quality and attaining the most recent National Ambient Air Quality Standards are likely to require coordinated efforts on regional scales to broadly reduce $\mathrm{NO}_{x}$ emissions.
Data availability. Data from previous field campaigns are available at the following locations: https://esrl.noaa.gov/csd/groups/ csd7/measurements/2002ITCT/P3/DataDownload/ (ITCT Science Team, 2002); https://doi.org/10.5067/asdcdaac/intexa/0008 (INTEX-A Science Team, 2006); https://doi.org/10.5067/asdcdaac/intexb/0008 (INTEX-B Science Team, 2011); https://doi.org/10.5281/zenodo.3593409 (BEARPEX 07 Science Team, 2007); https://www-air.larc.nasa. gov/cgi-bin/ArcView/arctas (ARCTAS-B Science Team, 2011); https://doi.org/10.5281/zenodo.3593413 (BEARPEX 09 Science Team, 2009); https://esrl.noaa.gov/csd/groups/csd7/measurements/ 2010calnex/P3/DataDownload/ (CALNEX Science Team, 2002a); https://esrl.noaa.gov/csd/groups/csd7/measurements/ 2010calnex/Bakersfield/DataDownload/ (CALNEX Science Team, 2002b); https://doi.org/10.5067/aircraft/dc3/dc8/aerosoltracegas (DC3 Science Team, 2013); https://esrl.noaa.gov/csd/ groups/csd7/measurements/2013senex/Ground/DataDownload/ (SOAS Science Team, 2013); https://www-air.larc.nasa. gov/cgi-bin/ArcView/seac4rs (SEAC4RS Science Team, 2014); https://www-air.larc.nasa.gov/cgi-bin/ArcView/ discover-aq.co-2014?C130=1 (FRAPPÉ Science Team, 2014); https://doi.org/10.5067/Suborbital/KORUSAQ/DATA01 (KORUSAQ Science Team, 2018). The BEHR retrieval of OMI $\mathrm{NO}_{2}$ columns is available at https://doi.org/10.6078/D1RQ3G (Laughner et al., 2018b). 


\section{Appendix A: Calculation of the $\mathrm{RONO}_{2}$ production rate}

\section{A1 Steady-state calculation of unmeasured radicals}

The formation rates of $\mathrm{RONO}_{2}, \mathrm{HNO}_{3}$, and $\mathrm{O}_{3}$ depend either directly or indirectly on the concentration of $\mathrm{OH}, \mathrm{HO}_{2}, \mathrm{RO}_{2}$, $\mathrm{NO}$, and $\mathrm{NO}_{2}$. Speciated $\mathrm{RO}_{2}$ radicals are not currently observable in the atmosphere, and thus all $\mathrm{RO}_{2}$ concentrations were calculated assuming they were in steady state, with their production and loss rates equal.

There were additional periods in which some combination of $\mathrm{OH}, \mathrm{HO}_{2}$, and $\mathrm{NO}$ were also not measured, and these radicals were also assumed to be in steady state. Concentrations of VOCs, $\mathrm{NO}_{2}$, and $\mathrm{O}_{3}$ were always taken from measurements. In order to calculate the steady-state concentrations of unmeasured radicals, reaction rate constants and $\mathrm{RO}_{2}$ yields for the different VOCs were taken from the MCM v3.3.1 (Jenkin et al., 2015). Concentrations of all unmeasured species were calculated iteratively until all the concentrations converged. Equations (A1-A8) were used to calculate the steady-state concentration of unmeasured radicals. In Eq. (A8), the symbol XR is used to represent the $\mathrm{OH}$ reactivity of species such as $\mathrm{SO}_{2}$ and $\mathrm{O}_{3}$ that are not included in either VOCR or NO2R. Although it is not often categorized as a VOC, CO is included as a contributor to VOCR. The reaction rate constant for $\mathrm{NO}_{2}$ with $\mathrm{OH}$ was taken from Mollner et al. (2010), with temperature and pressure dependencies from Henderson et al. (2012).

$$
\begin{aligned}
& P\left(\mathrm{RO}_{2}\right)=[\mathrm{OH}] \cdot \mathrm{VOCR} \cdot Y_{\mathrm{RO}_{2}} \text {, } \\
& L\left(\mathrm{RO}_{2}\right)=k_{\mathrm{RO}_{2}+\mathrm{NO}}\left[\mathrm{RO}_{2}\right][\mathrm{NO}]+k_{\mathrm{RO}_{2}+\mathrm{HO}_{2}}\left[\mathrm{RO}_{2}\right]\left[\mathrm{HO}_{2}\right] \\
& +2 k_{\mathrm{RO}_{2}+\mathrm{RO}_{2}}\left[\mathrm{RO}_{2}\right]\left[\mathrm{RO}_{2}\right]+k_{\text {isom }}\left[\mathrm{RO}_{2}\right] \text {, } \\
& P\left(\mathrm{HO}_{2}\right)=k_{\mathrm{RO}_{2}+\mathrm{NO}}\left[\mathrm{RO}_{2}\right][\mathrm{NO}](1-\alpha)+[\mathrm{OH}] \\
& \cdot \mathrm{VOCR} \cdot Y_{\mathrm{HO}_{2}}+2 j_{\mathrm{HCHO}}[\mathrm{HCHO}] \text {, } \\
& L\left(\mathrm{HO}_{2}\right)=k_{\mathrm{HO}_{2}+\mathrm{NO}}\left[\mathrm{HO}_{2}\right][\mathrm{NO}]+2 k_{\mathrm{HO}_{2}+\mathrm{HO}_{2}}\left[\mathrm{HO}_{2}\right]\left[\mathrm{HO}_{2}\right] \\
& +k_{\mathrm{HO}_{2}+\mathrm{RO}_{2}}\left[\mathrm{HO}_{2}\right]\left[\mathrm{RO}_{2}\right] \text {, } \\
& P(\mathrm{NO})=j_{\mathrm{NO}_{2}}\left[\mathrm{NO}_{2}\right] \text {, } \\
& L(\mathrm{NO})=k_{\mathrm{O}_{3}+\mathrm{NO}}\left[\mathrm{O}_{3}\right][\mathrm{NO}]+k_{\mathrm{RO}_{2}+\mathrm{NO}}\left[\mathrm{RO}_{2}\right][\mathrm{NO}] \\
& +k_{\mathrm{HO}_{2}+\mathrm{NO}}\left[\mathrm{HO}_{2}\right][\mathrm{NO}] \text {, } \\
& P(\mathrm{OH})=\frac{2 j_{\mathrm{O}_{3} \rightarrow \mathrm{O}^{1} \mathrm{D}}\left[\mathrm{O}_{3}\right] \cdot k_{\mathrm{O}^{1} \mathrm{D}+\mathrm{H}_{2} \mathrm{O}}\left[\mathrm{H}_{2} \mathrm{O}\right]}{k_{\mathrm{O}^{1} \mathrm{D}+\mathrm{H}_{2} \mathrm{O}}\left[\mathrm{H}_{2} \mathrm{O}\right]+k_{\mathrm{O}^{1} \mathrm{D}+\mathrm{M}}[\mathrm{M}]} \\
& +j_{\mathrm{HONO}}[\mathrm{HONO}]+k_{\mathrm{HO}_{2}+\mathrm{NO}}\left[\mathrm{HO}_{2}\right][\mathrm{NO}]+ \\
& k_{\mathrm{O}_{3}+\mathrm{RH}}\left[\mathrm{O}_{3}\right][\mathrm{RH}] Y_{\mathrm{OH}} \text {, } \\
& L(\mathrm{OH})=(\mathrm{VOCR}+\mathrm{NO} 2 \mathrm{R}+\mathrm{XR})[\mathrm{OH}] .
\end{aligned}
$$

In order to test the accuracy of the modeling, we used periods when $\mathrm{HO}_{2}, \mathrm{OH}$, and $\mathrm{NO}$ were all measured and calculated how the production ratio $P\left(\mathrm{RONO}_{2}\right) / P\left(\mathrm{HNO}_{3}\right)$ changed if modeled radical concentrations were substituted for the measured values. These results are shown in Fig. A1. Even in the worst-case scenario (modeled concentrations used for all radicals), the slope is close to one (Fig. A1a),
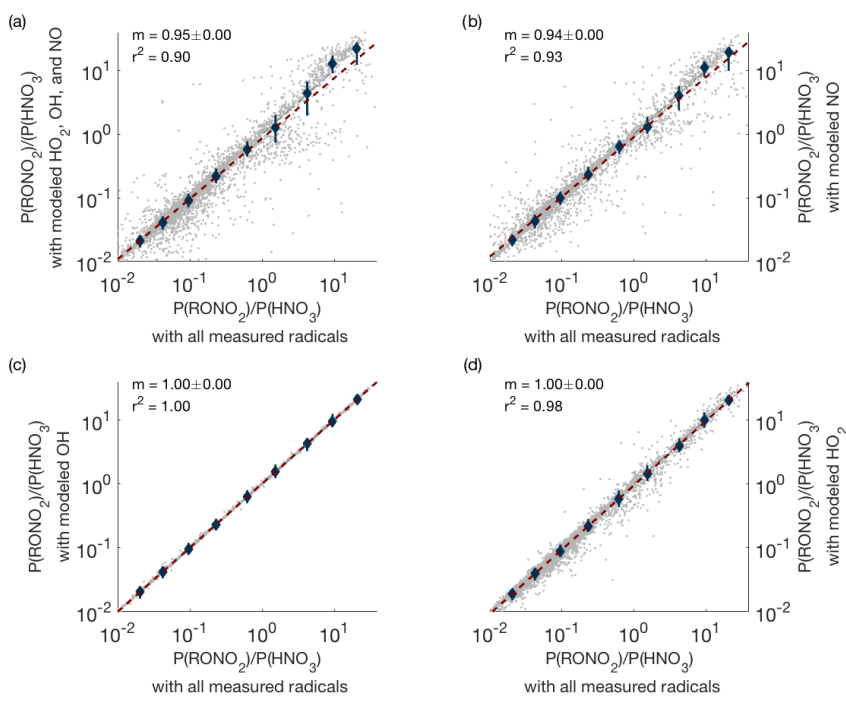

(d)

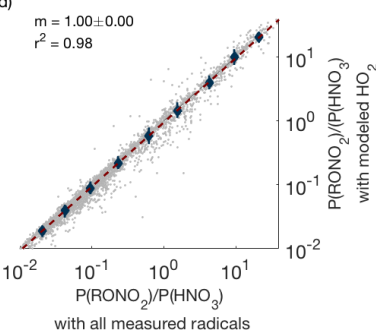

Figure A1. Comparison of $P\left(\mathrm{RONO}_{2}\right) / P\left(\mathrm{HNO}_{3}\right)$ when measured concentrations of all possible radicals are used ( $x$ axis) versus when measured concentrations are replaced by modeled concentrations ( $y$ axis). Panel (a) shows the result when modeled concentrations of $\mathrm{OH}, \mathrm{HO}_{2}$, and $\mathrm{NO}$ are all used simultaneously; panels (b-d) show the effect of replacing measured with modeled values one species at a time.

indicating that the use of modeled radicals does not significantly affect our results. Furthermore, Fig. A1b-d show that the use of modeled $\mathrm{OH}$ or $\mathrm{HO}_{2}$ concentrations alone does not lead to noticeable changes in $P\left(\mathrm{RONO}_{2}\right) / P\left(\mathrm{HNO}_{3}\right)$. Use of modeled NO concentrations can cause small but noticeable changes in $P\left(\mathrm{RONO}_{2}\right) / P\left(\mathrm{HNO}_{3}\right)$, but modeled NO concentrations are used in less than $3 \%$ of all data points used in this analysis (238 out of 7988 data points).

\section{A2 Determination of $\alpha$}

Accurately calculating the $\mathrm{RONO}_{2}$ production rate requires accurate knowledge of $\alpha_{i}$ for all VOCs. If values of $\alpha$ had been reported for a specific compound from laboratory measurements, the most recent value was applied (Perring et al., 2013; Teng et al., 2015; Rindelaub et al., 2015; Praske et al., 2015; Wennberg et al., 2018). In cases where no reliable laboratory measurements are available, the parameterization for $\alpha$ from Wennberg et al. (2018) was used. In all cases, the temperature and pressure dependencies described in Wennberg et al. (2018) were used to scale the laboratory measurements of $\alpha$ to the conditions of the atmosphere. 
Author contributions. PSRP and RCC designed the experiment; PSRP performed the analysis of field campaign data and wrote the paper with contributions from all authors; AZ designed, ran, and analyzed the modeling simulations; and RCC supervised the project.

Competing interests. The authors declare that they have no conflict of interest.

Acknowledgements. The authors thank Joshua Laughner for assistance with the OMI BEHR retrieval.

Financial support. This research has been supported by the National Oceanic and Atmospheric Administration, Climate Program Office (grant no. NA18OAR4310117) and the National Science Foundation, Division of Atmospheric and Geospace Sciences (grant no. AGS-1352972).

Review statement. This paper was edited by Astrid Kiendler-Scharr and reviewed by three anonymous referees.

\section{References}

ARCTAS-B Science Team: ARCTAS-B DC-8 aircraft data, NASA, available at: https://www-air.larc.nasa.gov/cgi-bin/ArcView/ arctas (last access: 13 July 2018), 2011.

BEARPEX 07 Science Team: BEARPEX 2007 field campaign data, https://doi.org/10.5281/zenodo.3593409, 2007.

BEARPEX 09 Science Team: BEARPEX 2009 field campaign data, https://doi.org/10.5281/zenodo.3593413, 2009.

Brown, S. S., Dubé, W. P., Fuchs, H., Ryerson, T. B., Wollny, A. G., Brock, C. A., Bahreini, R., Middlebrook, A. M., Neuman, J. A., Atlas, E., Roberts, J. M., Osthoff, H. D., Trainer, M., Fehsenfeld, F. C., and Ravishankara, A. R.: Reactive uptake coefficients for $\mathrm{N}_{2} \mathrm{O}_{5}$ determined from aircraft measurements during the Second Texas Air Quality Study: Comparison to current model parameterizations, J. Geophys. Res., 114, D00F10, https://doi.org/10.1029/2008JD011679, 2009.

Browne, E. C. and Cohen, R. C.: Effects of biogenic nitrate chemistry on the $\mathrm{NO}_{\mathrm{x}}$ lifetime in remote continental regions, Atmos. Chem. Phys., 12, 11917-11932, https://doi.org/10.5194/acp-1211917-2012, 2012.

Browne, E. C., Min, K.-E., Wooldridge, P. J., Apel, E., Blake, D. R., Brune, W. H., Cantrell, C. A., Cubison, M. J., Diskin, G. S., Jimenez, J. L., Weinheimer, A. J., Wennberg, P. O., Wisthaler, A., and Cohen, R. C.: Observations of total $\mathrm{RONO}_{2}$ over the boreal forest: $\mathrm{NO}_{\mathrm{x}}$ sinks and $\mathrm{HNO}_{3}$ sources, Atmos. Chem. Phys., 13, 4543-4562, https://doi.org/10.5194/acp-13-4543-2013, 2013.

CALNEX Science Team: CALNEX 2010 WP-3D data, NOAA, available at: https://esrl.noaa.gov/csd/groups/csd7/ measurements/2010calnex/P3/DataDownload/ (last access: 13 June 2018), 2002a.

CALNEX Science Team: CALNEX 2010 Bakersfield site data, NOAA, available at: https://esrl.noaa.gov/csd/groups/csd7/
measurements/2010calnex/Bakersfield/DataDownload/ (last access: 13 June 2018), 2002b.

Cooper, O. R., Gao, R.-S., Tarasick, D., Leblanc, T., and Sweeney, C.: Long-term ozone trends at rural ozone monitoring sites across the United States, 1990-2010, J. Geophys. Res.-Atmos., 117, D22307, https://doi.org/10.1029/2012JD018261, 2012.

DC3 Science Team: DC3 Field Campaign Data from DC-8 aircraft, NASA, https://doi.org/10.5067/aircraft/dc3/dc8/aerosoltracegas, 2013.

Edwards, P. M., Young, C. J., Aikin, K., deGouw, J., Dubé, W. P., Geiger, F., Gilman, J., Helmig, D., Holloway, J. S., Kercher, J., Lerner, B., Martin, R., McLaren, R., Parrish, D. D., Peischl, J., Roberts, J. M., Ryerson, T. B., Thornton, J., Warneke, C., Williams, E. J., and Brown, S. S.: Ozone photochemistry in an oil and natural gas extraction region during winter: simulations of a snow-free season in the Uintah Basin, Utah, Atmos. Chem. Phys., 13, 8955-8971, https://doi.org/10.5194/acp13-8955-2013, 2013.

Farmer, D. K., Perring, A. E., Wooldridge, P. J., Blake, D. R., Baker, A., Meinardi, S., Huey, L. G., Tanner, D., Vargas, O., and Cohen, R. C.: Impact of organic nitrates on urban ozone production, Atmos. Chem. Phys., 11, 4085-4094, https://doi.org/10.5194/acp11-4085-2011, 2011.

Fisher, J. A., Jacob, D. J., Travis, K. R., Kim, P. S., Marais, E. A., Chan Miller, C., Yu, K., Zhu, L., Yantosca, R. M., Sulprizio, M. P., Mao, J., Wennberg, P. O., Crounse, J. D., Teng, A. P., Nguyen, T. B., St. Clair, J. M., Cohen, R. C., Romer, P., Nault, B. A., Wooldridge, P. J., Jimenez, J. L., CampuzanoJost, P., Day, D. A., Hu, W., Shepson, P. B., Xiong, F., Blake, D. R., Goldstein, A. H., Misztal, P. K., Hanisco, T. F., Wolfe, G. M., Ryerson, T. B., Wisthaler, A., and Mikoviny, T.: Organic nitrate chemistry and its implications for nitrogen budgets in an isoprene- and monoterpene-rich atmosphere: constraints from aircraft (SEAC4RS) and ground-based (SOAS) observations in the Southeast US, Atmos. Chem. Phys., 16, 5969-5991, https://doi.org/10.5194/acp-16-5969-2016, 2016.

Fowler, D., Coyle, M., Skiba, U., Sutton, M. A., Cape, J. N., Reis, S., Sheppard, L. J., Jenkins, A., Grizzetti, B., Galloway, J. N., Vitousek, P., Leach, A., Bouwman, A. F., Butterbach-Bahl, K., Dentener, F., Stevenson, D., Amann, M., and Voss, M.: The global nitrogen cycle in the twenty-first century, Philos. T. Roy. Soc. B, 368, https://doi.org/10.1098/rstb.2013.0164, 2013.

FRAPPÉ Science Team: FRAPPÉ C-130 aircraft data, NASA, available at: https://www-air.larc.nasa.gov/cgi-bin/ArcView/ discover-aq.co-2014?C130=1 (last access: 21 March 2017), 2014.

Geddes, J. A., Murphy, J. G., and Wang, D. K.: Long term changes in nitrogen oxides and volatile organic compounds in Toronto and the challenges facing local ozone control, Atmos. Environ., 43, 3407-3415, https://doi.org/10.1016/j.atmosenv.2009.03.053, 2009.

Henderson, B. H., Pinder, R. W., Crooks, J., Cohen, R. C., Carlton, A. G., Pye, H. O. T., and Vizuete, W.: Combining Bayesian methods and aircraft observations to constrain the $\mathrm{HO}+\mathrm{NO}_{2}$ reaction rate, Atmos. Chem. Phys., 12, 653-667, https://doi.org/10.5194/acp-12-653-2012, 2012.

Hidy, G. M., Blanchard, C. L., Baumann, K., Edgerton, E., Tanenbaum, S., Shaw, S., Knipping, E., Tombach, I., Jansen, J., and Walters, J.: Chemical climatology of the southeastern United 
States, 1999-2013, Atmos. Chem. Phys., 14, 11893-11914, https://doi.org/10.5194/acp-14-11893-2014, 2014.

INTEX-A Science Team: INTEX-A DC-8 Aircraft data, NASA, https://doi.org/10.5067/asdcdaac/intexa/0008, 2006.

INTEX-B Science Team: INTEX-B DC-8 aircraft data, NASA, https://doi.org/10.5067/asdcdaac/intexb/0008, 2011.

ITCT Science Team: ITCT 2002 WP-3D Data, NOAA, available at: https://esrl.noaa.gov/csd/groups/csd7/measurements/2002ITCT/ P3/DataDownload/ (last access: 13 June 2018), 2002.

Jenkin, M. E., Young, J. C., and Rickard, A. R.: The MCM v3.3.1 degradation scheme for isoprene, Atmos. Chem. Phys., 15, 11433-11459, https://doi.org/10.5194/acp-15-11433-2015, 2015.

KORUS-AQ Science Team: KorUS-AQ Airborne Mission, NASA, https://doi.org/10.5067/Suborbital/KORUSAQ/DATA01, 2018.

Laughner, J. L., Zhu, Q., and Cohen, R. C.: The Berkeley High Resolution Tropospheric $\mathrm{NO}_{2}$ product, Earth Syst. Sci. Data, 10, 2069-2095, https://doi.org/10.5194/essd-10-2069-2018, 2018a.

Laughner, J., Zhu, Q., and Cohen, R. C.: Berkeley High Resolution (BEHR) $\mathrm{OMI} \mathrm{NO}_{2}$ - Gridded pixels, monthly profiles, https://doi.org/10.6078/D1RQ3G, 2018b.

Lee, B. H., Mohr, C., Lopez-Hilfiker, F. D., Lutz, A., Hallquist, M., Lee, L., Romer, P., Cohen, R. C., Iyer, S., Kurtén, T., Hu, W., Day, D. A., Campuzano-Jost, P., Jimenez, J. L., Xu, L., Ng, N. L., Guo, H., Weber, R. J., Wild, R. J., Brown, S. S., Koss, A., de Gouw, J., Olson, K., Goldstein, A. H., Seco, R., Kim, S., McAvey, K., Shepson, P. B., Starn, T., Baumann, K., Edgerton, E. S., Liu, J., Shilling, J. E., Miller, D. O., Brune, W., Schobesberger, S., D'Ambro, E. L., and Thornton, J. A.: Highly functionalized organic nitrates in the southeast United States: Contribution to secondary organic aerosol and reactive nitrogen budgets, P. Natl. Acad. Sci. USA, 113, 1516-1521, https://doi.org/10.1073/pnas.1508108113, 2016.

Lee, L., Wooldridge, P. J., Gilman, J. B., Warneke, C., de Gouw, J., and Cohen, R. C.: Low temperatures enhance organic nitrate formation: evidence from observations in the 2012 Uintah Basin Winter Ozone Study, Atmos. Chem. Phys., 14, 12441-12454, https://doi.org/10.5194/acp-14-12441-2014, 2014.

Mao, J., Ren, X., Brune, W. H., Olson, J. R., Crawford, J. H., Fried, A., Huey, L. G., Cohen, R. C., Heikes, B., Singh, H. B., Blake, D. R., Sachse, G. W., Diskin, G. S., Hall, S. R., and Shetter, R. E.: Airborne measurement of $\mathrm{OH}$ reactivity during INTEX-B, Atmos. Chem. Phys., 9, 163-173, https://doi.org/10.5194/acp-9163-2009, 2009.

McDuffie, E. E., Fibiger, D. L., Dubé, W. P., Lopez-Hilfiker, F., Lee, B. H., Thornton, J. A., Shah, V., Jaeglé, L., Guo, H., Weber, R. J., Reeves, J. M., Weinheimer, A. J., Schroder, J. C., CampuzanoJost, P., Jimenez, J. L., Dibb, J. E., Veres, P., Ebben, C., Sparks, T. L., Wooldridge, P. J., Cohen, R. C., Hornbrook, R. S., Apel, E. C., Campos, T., Hall, S. R., Ullmann, K., and Brown, S. S.: Heterogeneous $\mathrm{N}_{2} \mathrm{O}_{5}$ Uptake During Winter: Aircraft Measurements During the 2015 WINTER Campaign and Critical Evaluation of Current Parameterizations, J. Geophys. Res.-Atmos., 123, 4345-4372, https://doi.org/10.1002/2018JD028336, 2018.

Mollner, A. K., Valluvadasan, S., Feng, L., Sprague, M. K., Okumura, M., Milligan, D. B., Bloss, W. J., Sander, S. P., Martien, P. T., Harley, R. A., McCoy, A. B., and Carter, W. P. L.: Rate of Gas Phase Association of Hy- droxyl Radical and Nitrogen Dioxide, Science, 330, 646-649, https://doi.org/10.1126/science.1193030, 2010.

Nguyen, T. B., Crounse, J. D., Teng, A. P., St. Clair, J. M., Paulot, F., Wolfe, G. M., and Wennberg, P. O.: Rapid deposition of oxidized biogenic compounds to a temperate forest, P. Natl. Acad. Sci. USA, 112, E392-E401, https://doi.org/10.1073/pnas.1418702112, 2015.

Perring, A. E., Bertram, T. H., Farmer, D. K., Wooldridge, P. J., Dibb, J., Blake, N. J., Blake, D. R., Singh, H. B., Fuelberg, H., Diskin, G., Sachse, G., and Cohen, R. C.: The production and persistence of $\sum \mathrm{RONO}_{2}$ in the Mexico City plume, Atmos. Chem. Phys., 10, 7215-7229, https://doi.org/10.5194/acp10-7215-2010, 2010.

Perring, A. E., Pusede, S. E., and Cohen, R. C.: An Observational Perspective on the Atmospheric Impacts of Alkyl and Multifunctional Nitrates on Ozone and Secondary Organic Aerosol, Chem. Rev., 113, 5848-5870, https://doi.org/10.1021/cr300520x, 2013.

Pollack, I. B., Ryerson, T. B., Trainer, M., Neuman, J. A., Roberts, J. M., and Parrish, D. D.: Trends in ozone, its precursors, and related secondary oxidation products in Los Angeles, California: A synthesis of measurements from 1960 to 2010, J. Geophys. Res.Atmos., 118, 5893-5911, https://doi.org/10.1002/jgrd.50472, 2013.

Praske, E., Crounse, J. D., Bates, K. H., Kurtén, T., Kjaergaard, H. G., and Wennberg, P. O.: Atmospheric Fate of Methyl Vinyl Ketone: Peroxy Radical Reactions with $\mathrm{NO}$ and $\mathrm{HO}_{2}$, J. Phys. Chem. A, 119, 4562-4572, https://doi.org/10.1021/jp5107058, 2015.

Pusede, S. E., Gentner, D. R., Wooldridge, P. J., Browne, E. C., Rollins, A. W., Min, K.-E., Russell, A. R., Thomas, J., Zhang, L., Brune, W. H., Henry, S. B., DiGangi, J. P., Keutsch, F. N., Harrold, S. A., Thornton, J. A., Beaver, M. R., St. Clair, J. M., Wennberg, P. O., Sanders, J., Ren, X., VandenBoer, T. C., Markovic, M. Z., Guha, A., Weber, R., Goldstein, A. H., and Cohen, R. C.: On the temperature dependence of organic reactivity, nitrogen oxides, ozone production, and the impact of emission controls in San Joaquin Valley, California, Atmos. Chem. Phys., 14, 3373-3395, https://doi.org/10.5194/acp-143373-2014, 2014.

Pusede, S. E., Duffey, K. C., Shusterman, A. A., Saleh, A., Laughner, J. L., Wooldridge, P. J., Zhang, Q., Parworth, C. L., Kim, H., Capps, S. L., Valin, L. C., Cappa, C. D., Fried, A., Walega, J., Nowak, J. B., Weinheimer, A. J., Hoff, R. M., Berkoff, T. A., Beyersdorf, A. J., Olson, J., Crawford, J. H., and Cohen, R. C.: On the effectiveness of nitrogen oxide reductions as a control over ammonium nitrate aerosol, Atmos. Chem. Phys., 16, 25752596, https://doi.org/10.5194/acp-16-2575-2016, 2016.

Pye, H. O. T., Luecken, D. J., Xu, L., Boyd, C. M., Ng, N. L., Baker, K. R., Ayres, B. R., Bash, J. O., Baumann, K., Carter, W. P. L., Edgerton, E. S., Fry, J. L., Hutzell, W. T., Schwede, D., and Shepson, P. B.: Modeling the Current and Future Roles of Particulate Organic Nitrates in the Southeastern United States, Environ. Sci. Technol., 49, 14195-14203, https://doi.org/10.1021/acs.est.5b03738, 2015.

Rindelaub, J. D., McAvey, K. M., and Shepson, P. B.: The photochemical production of organic nitrates from $\alpha$-pinene and loss via acid-dependent particle phase hydrolysis, Atmos. Environ., 100, 193-201, https://doi.org/10.1016/j.atmosenv.2014.11.010, 2015. 
Rollins, A. W., Browne, E. C., Min, K.-E., Pusede, S. E., Wooldridge, P. J., Gentner, D. R., Goldstein, A. H., Liu, S., Day, D. A., Russell, L. M., and Cohen, R. C.: Evidence for $\mathrm{NO}_{x}$ Control Over Nighttime SOA Formation, Science, 337, 1210-1212, https://doi.org/10.1126/science.1221520, 2012.

Romer, P. S., Duffey, K. C., Wooldridge, P. J., Allen, H. M., Ayres, B. R., Brown, S. S., Brune, W. H., Crounse, J. D., de Gouw, J., Draper, D. C., Feiner, P. A., Fry, J. L., Goldstein, A. H., Koss, A., Misztal, P. K., Nguyen, T. B., Olson, K., Teng, A. P., Wennberg, P. O., Wild, R. J., Zhang, L., and Cohen, R. C.: The lifetime of nitrogen oxides in an isoprene-dominated forest, Atmos. Chem. Phys., 16, 7623-7637, https://doi.org/10.5194/acp16-7623-2016, 2016.

Romer, P. S., Duffey, K. C., Wooldridge, P. J., Edgerton, E., Baumann, K., Feiner, P. A., Miller, D. O., Brune, W. H., Koss, A. R., de Gouw, J. A., Misztal, P. K., Goldstein, A. H., and Cohen, R. C.: Effects of temperature-dependent $\mathrm{NO}_{x}$ emissions on continental ozone production, Atmos. Chem. Phys., 18, 2601-2614, https://doi.org/10.5194/acp-18-2601-2018, 2018.

Rosen, R. S., Wood, E. C., Wooldridge, P. J., Thornton, J. A., Day, D. A., Kuster, W., Williams, E. J., Jobson, B. T., and Cohen, R. C.: Observations of total alkyl nitrates during Texas Air Quality Study 2000: Implications for $\mathrm{O}_{3}$ and alkyl nitrate photochemistry, J. Geophys. Res., 109, D07303, https://doi.org/10.1029/2003JD004227, 2004.

Russell, A. R., Valin, L. C., and Cohen, R. C.: Trends in OMI $\mathrm{NO}_{2}$ observations over the United States: effects of emission control technology and the economic recession, Atmos. Chem. Phys., 12, 12197-12209, https://doi.org/10.5194/acp-12-121972012, 2012.

SEAC4RS Science Team: SEAC4RS field campaign data, NASA, available at: https://www-air.larc.nasa.gov/cgi-bin/ArcView/ seac4rs (last access: 24 October 2017), 2014.

SOAS Science Team: SOAS 2013 Centreville site data, NOAA, available at: https://esrl.noaa.gov/csd/groups/csd7/ measurements/2013senex/Ground/DataDownload/ (last access: 17 June 2017), 2013.

Sobanski, N., Thieser, J., Schuladen, J., Sauvage, C., Song, W., Williams, J., Lelieveld, J., and Crowley, J. N.: Day and nighttime formation of organic nitrates at a forested mountain site in south-west Germany, Atmos. Chem. Phys., 17, 4115-4130, https://doi.org/10.5194/acp-17-4115-2017, 2017.

Stelson, A. W. and Seinfeld, J. H.: Relative humidity and temperature dependence of the ammonium nitrate dissociation constant, Atmos. Environ., 16, 983-992, https://doi.org/10.1016/00046981(82)90184-6, 1982.

Teng, A. P., Crounse, J. D., Lee, L., St. Clair, J. M., Cohen, R. C., and Wennberg, P. O.: Hydroxy nitrate production in the $\mathrm{OH}-$ initiated oxidation of alkenes, Atmos. Chem. Phys., 15, 42974316, https://doi.org/10.5194/acp-15-4297-2015, 2015.
Teng, A. P., Crounse, J. D., and Wennberg, P. O.: Isoprene Peroxy Radical Dynamics, J. Am. Chem. Soc., 139, 5367-5377, https://doi.org/10.1021/jacs.6b12838, 2017.

United States Environmental Protection Agency: Air Pollutant Emissions Trends Data, available at: https://www.epa.gov/ air-emissions-inventories/air-pollutant-emissions-trends-data (last access: 5 July 2018), 2018.

Warneke, C., de Gouw, J. A., Holloway, J. S., Peischl, J., Ryerson, T. B., Atlas, E., Blake, D., Trainer, M., and Parrish, D. D.: Multiyear trends in volatile organic compounds in Los Angeles, California: Five decades of decreasing emissions, J. Geophys. Res.Atmos., 117, D00V17, https://doi.org/10.1029/2012JD017899, 2012.

Wennberg, P. O., Bates, K. H., Crounse, J. D., Dodson, L. G., McVay, R. C., Mertens, L. A., Nguyen, T. B., Praske, E., Schwantes, R. H., Smarte, M. D., St Clair, J. M., Teng, A. P., Zhang, X., and Seinfeld, J. H.: Gas-Phase Reactions of Isoprene and Its Major Oxidation Products, Chem. Rev., 118, 3337-3390, https://doi.org/10.1021/acs.chemrev.7b00439, 2018.

Xiong, F., Borca, C. H., Slipchenko, L. V., and Shepson, P. B.: Photochemical degradation of isoprene-derived 4,1-nitrooxy enal, Atmos. Chem. Phys., 16, 5595-5610, https://doi.org/10.5194/acp-16-5595-2016, 2016.

Xu, L., Guo, H., Boyd, C. M., Klein, M., Bougiatioti, A., Cerully, K. M., Hite, J. R., Isaacman-VanWertz, G., Kreisberg, N. M., Knote, C., Olson, K., Koss, A., Goldstein, A. H., Hering, S. V., Gouw, J. d., Baumann, K., Lee, S.-H., Nenes, A., Weber, R. J., and Ng, N. L.: Effects of anthropogenic emissions on aerosol formation from isoprene and monoterpenes in the southeastern United States, P. Natl. Acad. Sci. USA, 112, 37-42, https://doi.org/10.1073/pnas.1417609112, 2015a.

$\mathrm{Xu}$, L., Suresh, S., Guo, H., Weber, R. J., and Ng, N. L.: Aerosol characterization over the southeastern United States using high-resolution aerosol mass spectrometry: spatial and seasonal variation of aerosol composition and sources with a focus on organic nitrates, Atmos. Chem. Phys., 15, 7307-7336, https://doi.org/10.5194/acp-15-7307-2015, 2015 b.

Zare, A., Romer, P. S., Nguyen, T., Keutsch, F. N., Skog, K., and Cohen, R. C.: A comprehensive organic nitrate chemistry: insights into the lifetime of atmospheric organic nitrates, Atmos. Chem. Phys., 18, 15419-15436, https://doi.org/10.5194/acp-18-154192018, 2018. 